\title{
Flotation of Carbonaceous Matter from a Double Refractory Gold Ore: The Effect of MIBC on Flotation Performance and Kinetics
}

\author{
Sugyeong Lee *(D), Charlotte E. Gibson (D) and Ahmad Ghahreman *(D) \\ The Robert M. Buchan Department of Mining, Queen's University, Kingston, ON K7L3N6, Canada; \\ charlotte.gibson@queensu.ca \\ * Correspondence: sugyeong.lee@queensu.ca (S.L.); ahmad.g@queensu.ca (A.G.)
}

check for updates

Citation: Lee, S.; Gibson, C.E.; Ghahreman, A. Flotation of Carbonaceous Matter from a Double Refractory Gold Ore: The Effect of MIBC on Flotation Performance and Kinetics. Minerals 2021, 11, 1021. https://doi.org/10.3390/min11091021

Academic Editor: Dave Deglon

Received: 26 August 2021

Accepted: 16 September 2021

Published: 19 September 2021

Publisher's Note: MDPI stays neutral with regard to jurisdictional claims in published maps and institutional affiliations.

Copyright: (c) 2021 by the authors. Licensee MDPI, Basel, Switzerland. This article is an open access article distributed under the terms and conditions of the Creative Commons Attribution (CC BY) license (https:/ / creativecommons.org/licenses/by/ $4.0 /)$.

\begin{abstract}
The use of alkaline pressure oxidation to pretreat refractory gold ore often results in insufficient gold recovery $(<60 \%)$ in downstream thiosulfate leaching. To improve gold recovery, flotation was considered for the separation of carbonaceous matter (C-matter). In this study, the effect of MIBC on C-matter flotation was investigated to understand the role of the frother in bubble and froth formation and on flotation kinetics. MIBC dosages between 30 and $150 \mathrm{~g} / \mathrm{t}$ were used in combination with $500 \mathrm{~g} / \mathrm{t}$ of kerosene as a collector. The results showed that the recovery and selectivity of $\mathrm{C}$-matter were improved with increasing MIBC dosages. Improved selectivity at higher MIBC dosages was attributed to faster C-matter recovery as bubble size decreased to the critical coalescence concentration (CCC) and to changes to the foam structure. Analysis of flotation kinetics showed that the flotation rate increased as the MIBC dosage increased due to the decreasing bubble size and the reduced induction time caused by the interaction between the collector and the frother. The results of this study explain the role of MIBC in C-matter flotation and can be used as a design basis for scavenger-cleaner flotation testing. Overall, the results show the potential for flotation as a means to improve gold recovery in thiosulfate leaching through the removal of C-matter.
\end{abstract}

Keywords: carbonaceous matter flotation; frother; kinetics study; MIBC effect; refractory gold ore

\section{Introduction}

Due to insufficient gold recovery by direct cyanidation, refractory gold ores require pretreatment prior to gold extraction. Properties indicative of refractory gold ores are: preg-robbing caused by carbonaceous matter (C-matter) present in the ore, gold locked in sulfide or silicate minerals, and cyanide- and oxygen-consuming matter (e.g., copper, sulfide minerals) [1-3]. Gold ore from Barrick's Goldstrike mine (Nevada, USA) is a typical type of refractory gold ore containing both sulfide and C-matter. Some golds are locked in sulfide and the presence of C-matter leads to low gold recovery by cyanidation. At the Goldstrike mine, the ground ore is treated by pressure oxidation (POX) to liberate gold from sulfides followed by thiosulfate leaching to avoid the preg-robbing effect caused by C-matter [4]. However, gold recovery from the discharge of alkaline POX tends to be insufficient ( $<60 \%$ after $24 \mathrm{~h}$ of thiosulfate leaching under laboratory conditions). In general, the low gold recovery results from iron oxide passivation on gold particles during the POX process and from insufficiently oxidized sulfide minerals [5]. Deficient oxidation rate caused by passivation can lead to the incomplete liberation of fine gold in sulfides [6]. In addition, in the alkaline POX discharge, unextractable gold was detected as the adsorbed gold on C-matter after thiosulfate leaching, further contributing to low gold recovery. To improve overall gold recovery, C-matter flotation was considered as a pretreatment method, with the objective to concentrate the $\mathrm{C}$-matter for treatment at the Goldstrike roaster, rather than by POX. Following flotation, the concentrate and tailings are processed by different processes, as shown in Figure 1. The C-matter concentrate is treated by the roaster, which is 
capable of decomposing the C-matter, resulting in high gold recovery. The flotation tailings are then treated by the alkaline POX process to liberate gold from sulfides. The proposed process uses an alkaline POX process for tailings, but an increase in total gold recovery can be expected by increasing gold recovery on C-matter concentrate by roasting. Since the roaster plant of Goldstrike has limited additional capacity, selective flotation of C-matter is required to ensure that as much $\mathrm{C}$-matter flotation is selective as possible, to minimize the mass in the flotation concentrate.

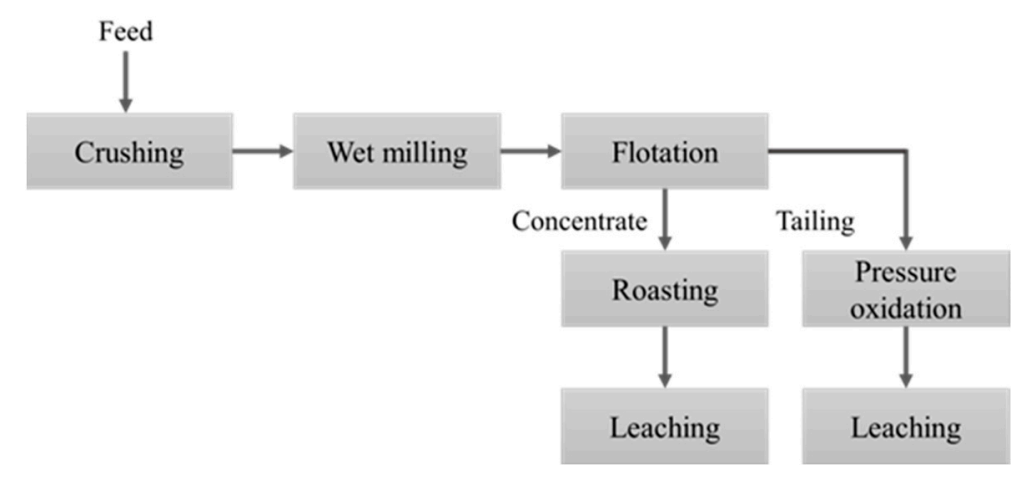

Figure 1. The proposed process for the treatment of refractory gold ore.

As a first step in identifying the optimal conditions for C-matter flotation from Goldstrike ore, the effect of methyl isobutyl carbonyl (MIBC) as a frother was investigated, with a focus on bubble and foam/froth formation. In flotation, it is well known that the frother reduces the bubble size by preventing bubble coalescence [7,8]; therefore, bubble size decreases with increasing frother concentration until it reaches a minimum. The frother concentration after which bubble size remains constant is known as the critical coalescence concentration (CCC) $[7,8]$. The CCC is a function of the frother type; MIBC is reported to have a CCC between 9 and $12 \mathrm{ppm}[7,9-11]$. As the MIBC concentration increases, the Sauter mean diameter of bubble $\left(\mathrm{D}_{32}\right)$ decreases from $2.0-4.0 \mathrm{~mm}$ at $0 \mathrm{ppm}$ to around $1.0 \mathrm{~mm}$ at the CCC, depending on test conditions $[7,9,10,12]$. With an increase in MIBC concentration from CCC to $15-100 \mathrm{ppm}$, the $\mathrm{D}_{32}$ shows a minor change of $\sim 0.3 \mathrm{~mm}$. It has been demonstrated that bubble size is reduced by breakup, which is promoted by unstable bubble surface, as more frother is added [12-14]. The frother changes the bubble velocity as bubbles with a frother rise more slowly than those without a frother [15-17]. This decreased bubble rise speed in the presence of a frother is attributed to a change in drag force, caused by interaction between the frother and water molecules, bubble size, and bubble shape (more spherical bubbles are formed with a frother) [15,18-20]. The rise speed of bubbles influences the probability of collision in flotation, ultimately influencing flotation performance [15].

In addition to its impact on bubbles, the frother contributes to changes in foamability and froth structure. Unstable froth can lead to recovery losses, and therefore froth structure is an important parameter in effective flotation [21]. Several studies have reported that foamability increases with increasing frother concentration [10,22-24]. Zheng et al. [25] demonstrated that increased froth height and retention time result in reduced entrainment. Further, the frother induces changes in the froth structure. Foam is classified as either wet foam or dry foam; wet foam has a thicker liquid wall between bubbles and while it carries more water, it can also have better drainage [26,27]. In spite of this, studies by Smith and Warren [28] and Zheng et al. [25] showed that fine particle entrainment decreases as water recovery to the concentrate decreases. This observation is supported by Barbian et al. [29], who demonstrated that foam stability affects flotation performance in grade.

Researchers have also shown that flotation kinetics is influenced by the frother addition. It has been demonstrated that specific bubble surface area $(\mathrm{Sb})$ positively correlates with the first-order rate constant [30]; as bubble size decreases ( $\mathrm{Sb}$ increases), the probability of collision and solid-carrying capacity increases, increasing flotation rate. It has also 
been proposed that the frother influences flotation kinetics by decreasing the induction time (i.e., the time required for the thin film of water between the air bubble and mineral particle to rupture, allowing the particle to attach to the air bubble). Reduced induction time is attributed to an interaction between the collector and the frother, where the collector adsorbed at the mineral surface interacts with the frother at the gas/water interface when particle and bubble are collided and attached, increasing the critical film thickness and attachment [31,32]. The higher the frother concentration in solution, the stronger the interaction with the collector, which results in a higher flotation rate. Flotation kinetics is related to the probability of collection $(\mathrm{P})$, which in flotation is explained by the probability of adhesion (Pa) and collision (Pc) [32,33]. Changes in Pa and Pc caused by the frother lead to a flotation kinetics difference.

In this study, a total of four kinetics models were selected: classical first-order, modified first-order (Agar), improved gas/solid adsorption, and first-order with rectangular distribution (Klimpel). Typically, the classical first-order model is applied to systems with monodisperse feed under the assumption that all particles have the same floatability [34]. The Agar and Klimpel models are derived from the classical first-order model with the addition of a time correction factor and the assumption of a rectangular distribution of particle floatability, respectively [35]. The improved gas/solid adsorption model is similar to the fully mixed model, which inverts the rate constant and is sometimes preferred as it explains the monodisperse feed using an exponential distribution of particle floatability [36]. Due to the presence of the aforementioned modifying factors, the Agar, Klimpel, and improved gas/sold adsorption models have been observed to better describe flotation kinetics compared to the classical first-order model. Other flotation models were not considered in this study, as they have generally been observed to have a poorer fit to most flotation systems [34] and the first-order kinetics model is viewed as sufficient to explain flotation kinetics [37]. The selected models are summarized in Table 1 , where $R_{\infty}, k$, and $b$ are the ultimate recovery, the rate constant, and the time correction factor, respectively.

Table 1. Selected flotation kinetics models.

\begin{tabular}{cc}
\hline Model & Flotation Rate Equation \\
\hline Classical first-order & $\mathrm{R}=\mathrm{R}_{\infty}\left(1-\mathrm{e}^{-\mathrm{kt}}\right)$ \\
Modified first-order (Agar) & $\mathrm{R}=\mathrm{R}_{\infty}\left(1-\mathrm{e}^{-\mathrm{k}(\mathrm{t}+\mathrm{b})}\right)$ \\
Improved gas/solid adsorption & $\mathrm{R}=\mathrm{R}_{\infty}\left(\frac{\mathrm{kt}}{1+\mathrm{kt}}\right)$ \\
$\begin{array}{c}\text { First-order with rectangular } \\
\text { distribution (Klimpel) }\end{array}$ & $\mathrm{R}=\mathrm{R}_{\infty}\left[1-\frac{1}{\mathrm{kt}}\left(1-\mathrm{e}^{-\mathrm{kt}}\right)\right]$ \\
\hline
\end{tabular}

As discussed above, the frother affects bubbles and foam/froth in flotation. However, the frother also interacts with particles and the froth structure is affected by solids [17,27]. Thus, the effect of the frother can differ depending on the ore type. This study examines how MIBC influences C-matter rougher flotation performance (recovery, selectivity, and kinetics). Our results could then be extended to scavenger and cleaner flotations with the ultimate goal of efficient C-matter separation, leading to higher overall gold recovery. Our results not only determine the effect of MIBC on C-matter, but also suggest the possibility of flotation as the alternative method for refractory gold ore containing $\mathrm{C}$-matter, leading to overall increased gold recovery.

\section{Materials and Methods}

\subsection{Materials}

The flotation feed used in this study was double refractory gold ore containing both carbonaceous matter and sulfide from Barrick's flagship Goldstrike mine in Nevada, USA. $X$-ray diffraction (XRD) analysis results showed that the sample contained primarily quartz and dolomite with minor of pyrite and calcite (Figure 2). To determine the minor quantities of other matters, which were not detected by XRD, additional analyses were performed. 
The elemental contents of the ore sample were analyzed by sodium peroxide fusion and fire assay followed by inductively coupled plasma optical emission spectrometry (ICPOES) analysis. Total carbon content and C-matter content were analyzed by $\mathrm{C} / \mathrm{S}$ analysis (ELTRA, CS-2000). In this study, C-matter content indicated the amount of all carbon except for carbon from carbonate minerals. For analysis, $\mathrm{HCl}$ dissolution at $60{ }^{\circ} \mathrm{C}$ was carried out to dissolve all carbonate minerals and samples before and after $\mathrm{HCl}$ dissolution were weighed and analyzed for $\mathrm{C} / \mathrm{S}$ contents. The details are presented in Table 2. It contained $5.93 \%$ of total carbon with $1.95 \%$ of $\mathrm{C}$-matter, $1.33 \%$ of $\mathrm{S}, 2.14 \mathrm{~g} / \mathrm{t}$ of gold, and others $(\mathrm{Ca}$, $\mathrm{Mg}$, Fe, and $\mathrm{Al})$.

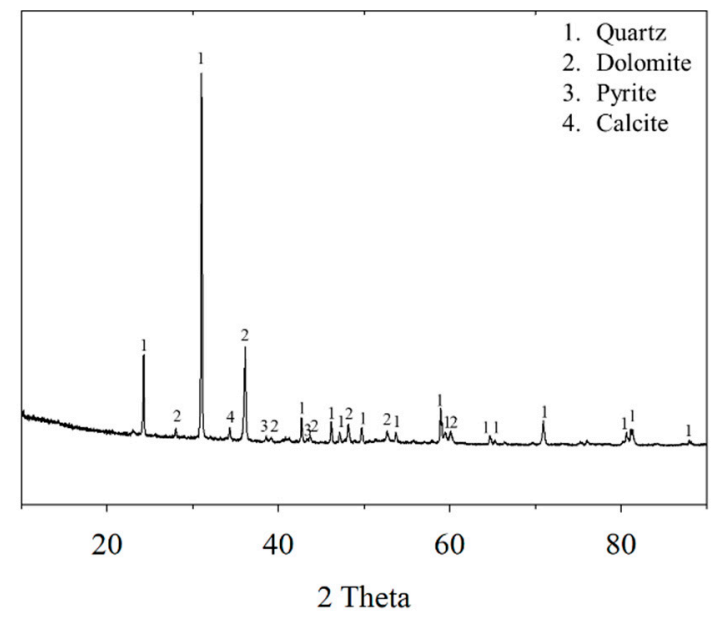

Figure 2. XRD analysis result of sample ore.

Table 2. Element contents of sample ore.

\begin{tabular}{ccccccc}
\hline Ca (\%) & Mg (\%) & Fe (\%) & S (\%) & Al (\%) & $\begin{array}{c}\text { Tot. C } \\
(\text { C-Matter \%) }\end{array}$ & Au (g/t) \\
\hline 7.92 & 3.96 & 1.32 & 1.33 & 2.21 & $5.93(1.95)$ & 2.14 \\
\hline
\end{tabular}

\subsection{Methods}

The flotation experiments were carried out using a Denver laboratory flotation machine in a $2.5 \mathrm{~L}$ flotation cell. The impeller speed was $1200 \mathrm{rpm}$ for both conditioning and collecting. The experiment was performed at a natural $\mathrm{pH}$ of 7-8. The ground sample was mixed with tap water for $3 \mathrm{~min}$ in the flotation cell at $25 \%$ pulp density $(\mathrm{w} / \mathrm{w})$, and then the kerosene and MIBC were added as the collector and frother, respectively. Kerosene dosage was constant at $500 \mathrm{~g} / \mathrm{t}$ and the MIBC dosage increased from 30 to $150 \mathrm{~g} / \mathrm{t}$ (9-47 ppm in the pulp, Table 3). The dosage of kerosene $(500 \mathrm{~g} / \mathrm{t})$ was identified through a series of bench scale flotation tests conducted with varying concentrations of kerosene at a constant MIBC dosage. These tests showed that as the kerosene dosage increased from 50 to $500 \mathrm{~g} / \mathrm{t}, \mathrm{C}-$ matter recovery improved from 40 to $55 \%$ (with a feed particle size of $80 \%$ passing $67.7 \mu \mathrm{m}$ and $60 \mathrm{~g} / \mathrm{t}$ of MIBC). Thus, subsequent testing on the effect of MIBC was conducted using $500 \mathrm{~g} / \mathrm{t}$ of kerosene. The conditioning time for the kerosene and MIBC was $1 \mathrm{~min}$ each (kerosene was added first, followed by MIBC). For the flotation kinetics study, the froth was collected at $0.5,1.5,2.5,4.5$, and $6.5 \mathrm{~min}$. The 5 distinct concentrates and the final tailings were dried, then weighed. All tests were repeated, showing less than $3 \%$ difference in the final recovery. Those samples were dissolved in a $\mathrm{HCl}$ solution at $60{ }^{\circ} \mathrm{C}$ to analyze C-matter with the removal of carbonates. Carbon and sulfur contents before and after acid dissolution were determined by a C/S analyzer (ELTRA, CS 2000). 
Table 3. MIBC dosages and concentrations in the pulp.

\begin{tabular}{cccccc}
\hline $\mathbf{( g / t )}$ & $\mathbf{3 0}$ & $\mathbf{6 0}$ & $\mathbf{9 0}$ & $\mathbf{1 2 0}$ & $\mathbf{1 5 0}$ \\
\hline$(\mathrm{ppm})$ & 9 & 19 & 28 & 38 & 47 \\
\hline
\end{tabular}

\section{Results and Discussion}

\subsection{The Effect of MIBC Dosage on Recovery}

Flotation tests were carried out with $500 \mathrm{~g} / \mathrm{t}$ of kerosene on ground ore samples (P80: $36.5 \mu \mathrm{m}$ ) and the dosage of MIBC was changed from $30 \mathrm{~g} / \mathrm{t}$ to $150 \mathrm{~g} / \mathrm{t}$. The results showed improved recovery by increasing MIBC dosage from $30 \mathrm{~g} / \mathrm{t}$ to $60 \mathrm{~g} / \mathrm{t}$ (Figure 3 ). As the MIBC dosage increased to $150 \mathrm{~g} / \mathrm{t}$, recovery in the initial moments of flotation increased. However, the final recovery after $6.5 \mathrm{~min}$ of flotation was nearly the same $(\sim 69 \%)$ with $60-150 \mathrm{~g} / \mathrm{t}$ of MIBC, indicating that an MIBC addition greater than $60 \mathrm{~g} / \mathrm{t}$ had no effect on the ultimate C-matter recovery, only on flotation kinetics. The CCC of MIBC was between 9 and 12 ppm [7,9-11]. Thus, we expected that the MIBC concentration reached the CCC somewhere between 30 and $60 \mathrm{~g} / \mathrm{t}$ (9 and $19 \mathrm{ppm}$, Table 3), resulting in a significant increase in C-matter recovery at $60 \mathrm{~g} / \mathrm{t}$. The lower recovery observed at $30 \mathrm{~g} / \mathrm{t}$ of MIBC can be attributed to an insufficient amount of MIBC, preventing the formation of fine bubbles and stable froth. As bubble size decreases, the collision and attachment between bubbles and particles increase since the total bubble surface area increases, leading to increased recovery [38]. Above $60 \mathrm{~g} / \mathrm{t}$, excess MIBC was shown to influence the flotation rate, but it offered no advantage in terms of the ultimate $\mathrm{C}$-matter recovery.

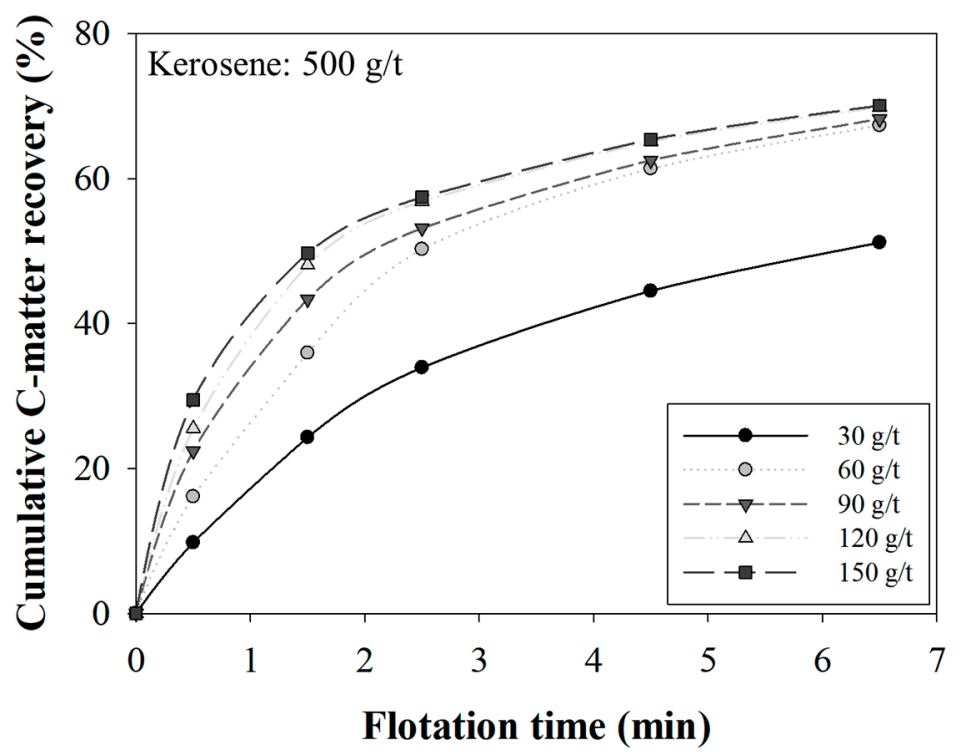

Figure 3. C-matter recovery as a function of MIBC dosage ( $30-150 \mathrm{~g} / \mathrm{t})$ : kerosene dosage, $500 \mathrm{~g} / \mathrm{t}$; agitation speed, $1200 \mathrm{rpm}$.

\subsection{The Effect of MIBC Dosage on the Selectivity}

The grade-recovery curves, presented in Figure 4, compare flotation performance and selectivity at different MIBC dosages. The higher MIBC dosages showed better overall flotation performance, as indicated by the shift in the curves from left to right (Figure 4). Increased selectivity in C-matter flotation was related to changes in entrainment and flotation kinetics as the MIBC dosage increased. 


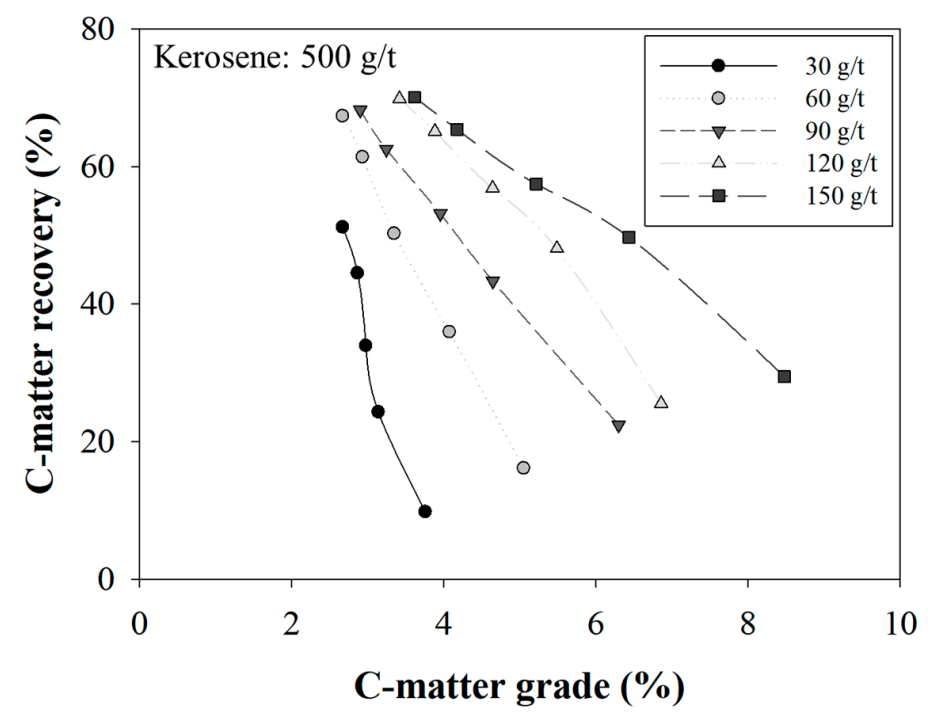

Figure 4. C-matter grade vs. C-matter recovery for different MIBC dosages: kerosene dosage, $500 \mathrm{~g} / \mathrm{t}$; agitation speed, $1200 \mathrm{rpm}$.

Ideally, the recovery of C-matter to the flotation concentrate occurs by true flotation with a high degree of selectivity. However, some amount of hydraulic entrainment of gangue minerals is inevitable, particularly in the flotation of fine particles. Entrainment is related to water recovery [38]; Figure 5 shows the water recovery to the concentrate as a function of flotation time to better understand the effect of the MIBC dosage on gangue entrainment. The results showed no significant difference in water recovery at 0.5 min of flotation for all MIBC dosages tested. This result is supported by a study conducted by Boylu and Laskowski [39] on water transfer rate with MIBC and emulsified diesel. The authors showed that the MIBC concentration does not affect the initial water transfer rate with a high concentration of collector. Thus, due to the high concentration of kerosene $(500 \mathrm{~g} / \mathrm{t})$ in this study, the MIBC dosage did not influence water recovery in the initial moments of flotation. However, as flotation time elapsed, a greater increase in water recovery was observed at lower dosages of MIBC, resulting in a lower final water recovery with higher MIBC dosages, with the exception of $30 \mathrm{~g} / \mathrm{t}$ of MIBC. The lowest water recovery was shown in the test with $30 \mathrm{~g} / \mathrm{t}$ dosage of MIBC at $6.5 \mathrm{~min}$. This anomaly can be attributed once again to an insufficient frother concentration, preventing the formation of fine bubbles-finer bubbles result in increased water recovery [13,40]. This result is supported by Yoon and Luttrell [41], whose work showed that reducing the bubble diameter increased both water recovery rate and coal recovery rate in flotation. However, the increase of coal recovery was much faster than that of water recovery, resulting in higher selectivity. Thus, the poor selectivity and lower water recovery observed at $30 \mathrm{~g} / \mathrm{t}$ of MIBC in the present study can be attributed to larger bubbles, as the frother dosage was below the CCC. Above $60 \mathrm{~g} / \mathrm{t}$, despite no difference in water recovery at $0.5 \mathrm{~min}$, selectivity was higher with a higher MIBC dosage (Figure 4). This can be explained by the flotation kinetics and froth properties. As can be seen in Figure 3, before $4.5 \mathrm{~min}$, both C-matter grade and recovery increased with higher MIBC dosages.

Improved selectivity observed with increasing MIBC dosages can also be related to entrainment. Kracht et al. [42] showed that PEG 300 (Polyethylene glycol) has a thicker and drier foam than octanol. With PEG 300, the selectivity of copper was higher than with octanol, even when water recovery was equal. The authors presented recovery by entrainment $\left(\mathrm{R}_{\mathrm{ENT}}\right)$ as a function of entrainment factor (ENT) and water recovery $\left(\mathrm{R}_{\mathrm{w}}\right)[25,42]$ :

$$
\mathrm{R}_{\mathrm{ENT}}=\mathrm{ENT} \times \mathrm{R}_{\mathrm{W}}
$$




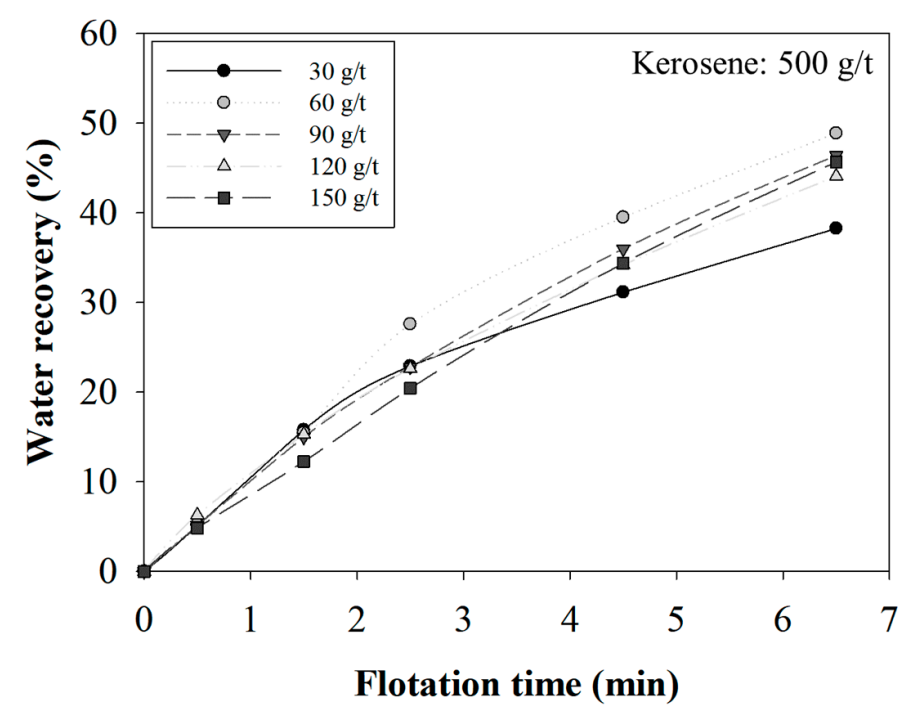

Figure 5. Water recovery changes for different MIBC dosages.

The study showed that PEG 300 has a lower ENT than octanol, resulting in less entrainment at equal water recovery values, attributed to differences in froth structure. Neethling et al. [43] claimed that closely packed bubbles have less water in the plateau border (i.e., where three lamellae - separate bubbles in foam-meet) at the pulp-froth interface than randomly packed bubbles. As previously discussed, it is also well known that wet foam contains more water than dry foam $[26,27]$. Figure 6 shows the froth collected using $120 \mathrm{~g} / \mathrm{t}$ of MIBC for each flotation time interval, illustrating that the froth was drier and more abundant in the initial stages of flotation $(0.5$ and $1.5 \mathrm{~min})$, while the froth dissipated with longer flotation times. During flotation testing, it was observed that the froth collected in the later stages collapsed instantly after collection. Further, the rate at which the froth collapsed increased with decreasing MIBC dosages, as did the perceived "wetness" of the froth. This observation suggests that at higher MIBC dosages, after 0.5 min of flotation, the froth was drier, leading to reduced hydraulic entrainment. Thus, a higher MIBC dosage likely affected the froth structure, as demonstrated by changes in water recovery and selectivity. Although froth height was not measured in this study, other studies have shown that higher froth height and retention time increase with frother concentration $[7,10,44]$, and they are therefore related to lower entrainment factor values, which tend to result in reduced gangue entrainment and high concentrate grade [25,45].
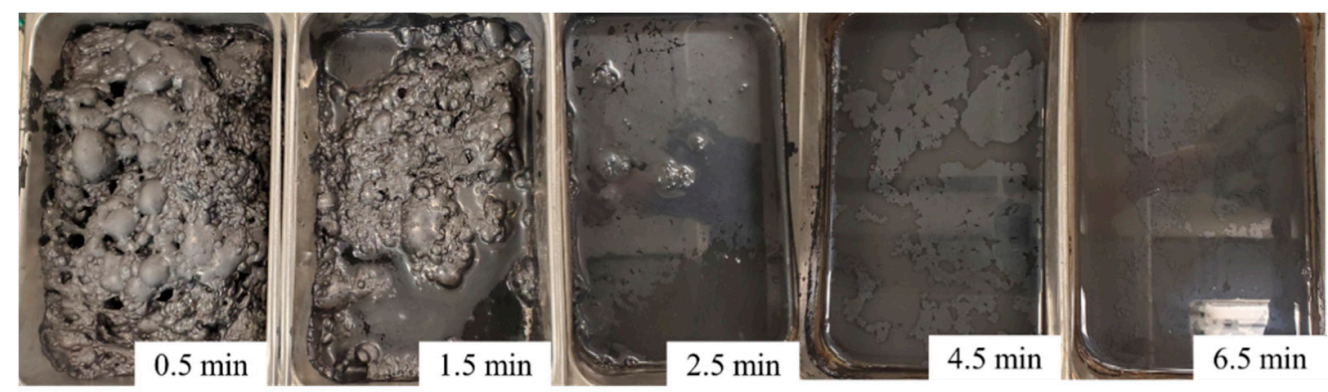

Figure 6. Foam changes for different flotation times: MIBC dosage, $120 \mathrm{~g} / \mathrm{t}$; kerosene dosage, $500 \mathrm{~g} / \mathrm{t}$; agitation speed, $1200 \mathrm{rpm}$.

\subsection{The Effect of the MIBC Dosage on Kinetics}

Flotation results were fit with four different kinetics models and the results are presented in Table 4. All models show acceptable fit, showing a high $R^{2}$ value $(>0.96)$. The rate constant increases with increasing MIBC dosages, while the ultimate recovery is similar for all MIBC dosages except for $30 \mathrm{~g} / \mathrm{t}$. The time correction factor (b) in the Agar model 
mostly increased as the MIBC concentration was increased. A positive b value indicates the attachment of hydrophobic particles to air bubbles during the conditioning period, before the air is added to the flotation cell [34]. Thus, the b value obtained in this study suggests that a higher MIBC dosage helps to expedite the froth stability and the flotation of the hydrophobic particles. Among the four models, the improved gas/solid adsorption model was selected as the representative one due to its highest $R^{2}$ value $\left(R^{2}>0.997\right.$ at all dosages). However, once again, the other kinetics models also show good fits and a trend similar to that of the improved gas/solid model against MIBC dosage changes.

Table 4. Kinetic model fitting results: $\mathrm{R}_{\infty}(\%)$, ultimate recovery; $\mathrm{k}\left(\mathrm{min}^{-1}\right)$, rate constant; $\mathrm{b}(\mathrm{min})$, time correction factor.

\begin{tabular}{cccccccccccccc}
\hline & \multicolumn{3}{c}{ Classical } & \multicolumn{4}{c}{ Agar } & \multicolumn{3}{c}{ Klimpel } & \multicolumn{3}{c}{ Improved Gas/Solid } \\
\hline $\mathbf{( g / t )}$ & $\mathbf{R}_{\infty}$ & $\mathbf{k}$ & $\mathbf{R}^{\mathbf{2}}$ & $\mathbf{R}_{\infty}$ & $\mathbf{k}$ & $\mathbf{b}$ & $\mathbf{R}^{\mathbf{2}}$ & $\mathbf{R}_{\infty}$ & $\mathbf{k}$ & $\mathbf{R}^{\mathbf{2}}$ & $\mathbf{R}_{\infty}$ & $\mathbf{k}$ & $\mathbf{R}^{\mathbf{2}}$ \\
\hline 30 & 55.4 & 0.38 & 0.9990 & 56.0 & 0.36 & 0.04 & 0.9992 & 66.0 & 0.66 & 0.9997 & 76.7 & 0.31 & 0.9995 \\
60 & 69.6 & 0.50 & 0.9986 & 70.1 & 0.48 & 0.04 & 0.9989 & 81.1 & 0.91 & 0.9987 & 91.1 & 0.45 & 0.9969 \\
90 & 66.8 & 0.70 & 0.9863 & 68.9 & 0.55 & 0.23 & 0.9969 & 75.3 & 1.39 & 0.9958 & 81.7 & 0.75 & 0.9996 \\
120 & 67.9 & 0.83 & 0.9846 & 69.6 & 0.66 & 0.22 & 0.9957 & 75.6 & 1.69 & 0.9969 & 81.1 & 0.94 & 0.9994 \\
150 & 67.0 & 0.96 & 0.9696 & 70.0 & 0.63 & 0.40 & 0.9947 & 73.7 & 2.04 & 0.9879 & 78.3 & 1.17 & 0.9978 \\
\hline
\end{tabular}

Figure 7 shows an increase in the flotation rate constant with increasing MIBC dosages. Increase in the flotation rate between 30 and $60 \mathrm{~g} / \mathrm{t}$ of MIBC can be explained by bubble size reduction occurring up to the CCC. Research by both Diaz-Penafiel and Dobby [46] and Ek [33] demonstrated that the probability of collision ( $\mathrm{Pc}$ ) increases as bubble size decreases, leading to higher flotation rates. The bubble size was reduced as the frother was added up to the CCC, leading to increasing bubble surface area and bubble-particle attachment effect.

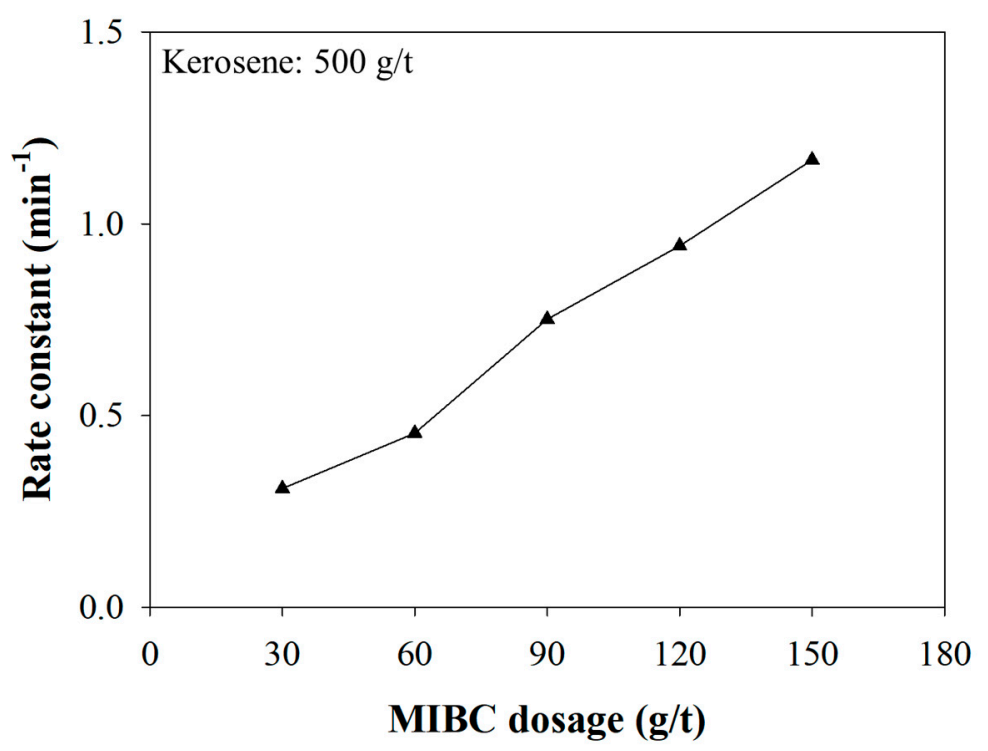

Figure 7. Flotation rate constant change against MIBC dosage: kerosene dosage, $500 \mathrm{~g} / \mathrm{t}$; agitation speed, $1200 \mathrm{rpm}$.

At $60 \mathrm{~g} / \mathrm{t}$, the MIBC dosage exceeded the CCC, yet the flotation rate constant continued to increase. Beyond the CCC, the increase in the rate constant was probably caused by a reduced induction time. The probability of adhesion $(\mathrm{Pa})$ can be explained by the induction time, which relates to the critical film thickness $\left(\mathrm{H}_{\mathrm{C}}\right)$ (i.e., a thin film of water ruptures spontaneously at this thickness) [47]. As the critical film thickness increases, the induction time reduces. The interaction between the collector and the frother-the collector adsorbed at the mineral surface and the frother at the gas/water interface-increases with the reagent concentration, increasing the critical film thickness and decreasing the induction 
time $[31,48,49]$. Thus, the higher the concentration of MIBC, the stronger its interaction with kerosene, resulting in faster flotation rates.

In summary, it is proposed that below the CCC, as the MIBC dosage increased, bubble size decreased, increasing the probability of collision (Pc). Beyond CCC, it is possible that the probability of adhesion (Pa) continued to increase as more MIBC was added, explaining the sustained increase in flotation rate. This increase in Pa may be attributed to the increased interaction effect between the collector and the frother described above, resulting in increased critical thickness $\left(\mathrm{H}_{\mathrm{C}}\right)$ and a reduced induction time.

\section{Conclusions}

As a means to design an effective carbonaceous matter flotation strategy, the effect of the MIBC dosage on flotation performance was investigated using $500 \mathrm{~g} / \mathrm{t}$ of kerosene as a collector. The role of MIBC in C-matter flotation was described and explained considering the effect of the frother on bubble size and froth stability. The major findings of this study are:

(1) Recovery: Higher dosages of MIBC resulted in higher C-matter recovery, regardless of flotation time. However, above $60 \mathrm{~g} / \mathrm{t}$ of MIBC, after $6.5 \mathrm{~min}$ of flotation, the ultimate recovery converged, independent of the frother dosage. Between 30 and $60 \mathrm{~g} / \mathrm{t}$ of MIBC, the difference in ultimate recovery was attributed to bubble size reduction, as the CCC was between 30 and $60 \mathrm{~g} / \mathrm{t}$ of MIBC. Decreasing bubble size led to more collision and attachment, resulting in higher C-matter recovery.

(2) Selectivity: Increased MIBC dosage showed an advantage in terms of C-matter selectivity, resulting in the best performance with $150 \mathrm{~g} / \mathrm{t}$ of MIBC. Improved selectivity resulted from decreasing entrainment and increasing flotation rate. As bubble size decreased between 30 and $60 \mathrm{~g} / \mathrm{t}$ of MIBC, water recovery also increased, but the C-matter recovery rate increase was faster than that of water, resulting in better selectivity at $60 \mathrm{~g} / \mathrm{t}$ of MIBC. Above $60 \mathrm{~g} / \mathrm{t}$ of MIBC, water recovery was slightly reduced due to changes in the froth structure and increased retention time. These changes led to better water drainage and less entrainment at higher MIBC dosages. Further, C-matter recovery was higher with higher MIBC dosages, resulting in an overall increase in selectivity.

(3) Kinetics: All four flotation kinetics models fit well, but the improved gas/solid adsorption model had the best fit. The rate constant showed a positive correlation with the MIBC dosage. Below the CCC (30-60 g/t of MIBC), this correlation was attributed to the bubble size reduction, which increased collision probability between bubbles and particles. Above the CCC (60-150 g/t of MIBC), bubble size was constant, suggesting that the flotation rate increased due to a strong interaction between the frother and collector, which strengthened with increasing MIBC dosages. This interaction led to an increasing critical film thickness and decreasing induction time, ultimately increasing the flotation rate.

To conclude, this study described the effect of MIBC dosage on C-matter flotation performance. The frother addition was shown to influence bubble size and froth stability during flotation, resulting in changes to recovery, selectivity and kinetics. The results obtained here will form the basis for the next stage of cleaner flotation testing to further improve C-matter separation. Overall, the study showed the potential to integrate Cmatter flotation into existing gold processing flowsheets, with the objective to produce tailored feed material for different downstream processing options (i.e., roasting and $\mathrm{POX} /$ thiosulfate leaching), ultimately improving overall gold recovery.

Author Contributions: Conceptualization, S.L., C.E.G. and A.G.; investigation, S.L.; software, S.L.; formal analysis, S.L.; data curation, S.L.; writing—original draft preparation, S.L.; writing—review and editing, C.E.G. and A.G.; supervision, C.E.G. and A.G.; project administration, A.G.; funding acquisition, A.G. All authors have read and agreed to the published version of the manuscript.

Funding: The authors acknowledge the financial support of the Natural Sciences and Engineering Research Council of Canada (NSERC), Ontario Centres for Excellence (OCE) and Barrick Gold Corp. for funding this project through the Collaborative Research and Development Grant program of NSERC (CRDPJ 522968-17), and OCE-VIP 2 project 30113. 


\section{Data Availability Statement: Not applicable.}

Conflicts of Interest: The authors declare no conflict of interest.

\section{References}

1. Komnitsas, C.; Pooley, F.D. Mineralogical characteristics and treatment of refractory gold ores. Miner. Eng. $1989,2,449-457$. [CrossRef]

2. La Brooy, S.R.; Linge, H.G.; Walker, G.S. Review of gold extraction from ores. Miner. Eng. 1994, 7, 1213-1241. [CrossRef]

3. Chen, T.T.; Cabri, L.J.; Dutrizac, J.E. Characterizing gold in refractory sulfide gold ores and residues. JOM 2002, 54, 20-22. [CrossRef]

4. Adams, M.D. (Ed.) Advances in Gold Ore Processing; Elsevier: Amsterdam, The Netherlands, 2005.

5. Thomas, K.G.; Pearson, M.S. Pressure oxidation overview. In Gold Ore Processing; Elsevier: Amsterdam, The Netherlands, 2016; pp. 341-358.

6. Aylmore, M.G.; de Klerk, L.W. Conditions and design considerations for maximising recoverable gold in roasting of refractory gold ores. In Proceedings of the World Gold Conference/Brisbane, Brisbane, QLD, Australia, 26-29 September 2013 ; pp. $26-29$.

7. Cho, Y.S.; Laskowski, J.S. Effect of flotation frothers on bubble size and foam stability. Int. J. Miner. Process. 2002, 64, 69-80. [CrossRef]

8. Grau, R.A.; Laskowski, J.S.; Heiskanen, K. Effect of frothers on bubble size. Int. J. Miner. Process. 2005, 76, 225-233. [CrossRef]

9. Laskowski, J.S. Testing flotation frothers. Physicochem. Probl. Miner. Process. 2004, 38, 13-22.

10. Gupta, A.K.; Banerjee, P.K.; Mishra, A.; Satish, P. Effect of alcohol and polyglycol ether frothers on foam stability, bubble size and coal flotation. Int. J. Miner. Process. 2007, 82, 126-137. [CrossRef]

11. Guven, O.; Batjargal, K.; Ozdemir, O.; Karakashev, S.I.; Grozev, N.A.; Boylu, F.; Çelik, M.S. Experimental procedure for the determination of the critical coalescence concentration (CCC) of simple frothers. Minerals 2020, 10, 617. [CrossRef]

12. Finch, J.A.; Nesset, J.E.; Acuña, C. Role of frother on bubble production and behaviour in flotation. Miner. Eng. 2008, 21, 949-957. [CrossRef]

13. Finch, J.A.; Gelinas, S.; Moyo, P. Frother-related research at McGill University. Miner. Eng. 2006, 19, 726-733. [CrossRef]

14. Kracht, W.; Finch, J.A. Bubble break-up and the role of frother and salt. Int. J. Miner. Process. 2009, 92, 153-161. [CrossRef]

15. Zhou, Z.A.; Egiebor, N.O.; Plitt, L.R. Frother effects on single bubble motion in a water column. Can. Metall. Q. 1992, 31, 11-16. [CrossRef]

16. Sam, A.; Gomez, C.O.; Finch, J.A. Axial velocity profiles of single bubbles in water/frother solutions. Int. J. Miner. Process. 1996, 47, 177-196. [CrossRef]

17. Rafiei, A.A.; Robbertze, M.; Finch, J.A. Gas holdup and single bubble velocity profile. Int. J. Miner. Process. 2011, 98, 89-93. [CrossRef]

18. Zhou, Z.A.; Egiebor, N.O.; Plitt, L.R. Frother effects on bubble motion in a swarm. Can. Metall. Q. 1993, 32, 89-96. [CrossRef]

19. Wu, M.; Gharib, M. Experimental studies on the shape and path of small air bubbles rising in clean water. Phys. Fluids 2002, 14, L49-L52. [CrossRef]

20. Kracht, W.; Finch, J.A. Effect of frother on initial bubble shape and velocity. Int. J. Miner. Process. 2010, 94, 115-120. [CrossRef]

21. Tsatouhas, G.; Grano, S.R.; Vera, M. Case studies on the performance and characterisation of the froth phase in industrial flotation circuits. Miner. Eng. 2006, 19, 774-783. [CrossRef]

22. Barbian, N.; Ventura-Medina, E.; Cilliers, J.J. Dynamic froth stability in froth flotation. Miner. Eng. 2003, 16, 1111-1116. [CrossRef]

23. Laskowski, J.S.; Cho, Y.S.; Ding, K. Effect of frothers on bubble size and foam stability in potash ore flotation systems. Can. J. Chem. Eng. 2003, 81, 63-69. [CrossRef]

24. Moreno, Y.S.; Bournival, G.; Ata, S. Foam stability of flotation frothers under dynamic and static conditions. Sep. Purif. Technol. 2020, 274, 117822. [CrossRef]

25. Zheng, X.; Johnson, N.W.; Franzidis, J.P. Modelling of entrainment in industrial flotation cells: Water recovery and degree of entrainment. Miner. Eng. 2006, 19, 1191-1203. [CrossRef]

26. Małysa, K. Wet foams: Formation, properties and mechanism of stability. Adv. Colloid Interface Sci. 1992, 40, 37-83. [CrossRef]

27. Melo, F.; Laskowski, J.S. Fundamental properties of flotation frothers and their effect on flotation. Miner. Eng. 2006, 19, 766-773. [CrossRef]

28. Smith, P.G.; Warren, L.J. Entrainment of particles into flotation froths. Miner. Process. Extr. Metall. Rev. 1989, 5, 123-145. [CrossRef]

29. Barbian, N.; Hadler, K.; Ventura-Medina, E.; Cilliers, J.J. The froth stability column: Linking froth stability and flotation performance. Miner. Eng. 2005, 18, 317-324. [CrossRef]

30. Gorain, B.K.; Franzidis, J.P.; Manlapig, E.V. Studies on impeller type, impeller speed and air flow rate in an industrial scale flotation cell. Part 4: Effect of bubble surface area flux on flotation performance. Miner. Eng. 1997, 10, 367-379. [CrossRef]

31. Laskowski, J.S. Frothers and flotation froth. Miner. Process. Extr. Metall. Rev. 1993, 12, 61-89. [CrossRef]

32. Yoon, R.H.; Luttrell, G.H. The effect of bubble size on fine particle flotation. Miner. Process. Extr. Metall. Rev. 1989, 5, 101-122. [CrossRef]

33. Ek, C. Flotation kinetics. In Innovations in Flotation Technology; Springer: Dordrecht, The Netherlands, 1992; pp. 183-210.

34. Sahoo, S.K.; Suresh, N.; Varma, A.K. Performance evaluation of basic flotation kinetic models using advanced statistical techniques. Int. J. Coal Prep. Util. 2019, 39, 65-87. [CrossRef] 
35. Bu, X.; Xie, G.; Peng, Y.; Ge, L.; Ni, C. Kinetics of flotation. Order of process, rate constant distribution and ultimate recovery. Physicochem. Probl. Miner. Process. 2017, 53, 342-365. [CrossRef]

36. Gharai, M.; Venugopal, R. Modeling of flotation process-An overview of different approaches. Miner. Process. Extr. Metall. Rev. 2016, 37, 120-133. [CrossRef]

37. Tao, D. Role of bubble size in flotation of coarse and fine particles-A review. Sep. Sci. Technol. 2005, 39, 741-760. [CrossRef]

38. Savassi, O.N.; Alexander, D.J.; Franzidis, J.P.; Manlapig, E.V. An empirical model for entrainment in industrial flotation plants. Miner. Eng. 1998, 11, 243-256. [CrossRef]

39. Boylu, F.; Laskowski, J.S. Rate of water transfer to flotation froth in the flotation of low-rank coal that also requires the use of oily collector. Int. J. Miner. Process. 2007, 83, 125-131. [CrossRef]

40. Dobby, G.S.; Finch, J. Particle collection in columns-Gas rate and bubble size effects. Can. Metall. Q. 1986, 25, 9-13. [CrossRef]

41. Yoon, R.H.; Luttrell, G.H. The effect of bubble size on fine coal flotation. Coal Prep. 1986, 2, 179-192. [CrossRef]

42. Kracht, W.; Orozco, Y.; Acuña, C. Effect of surfactant type on the entrainment factor and selectivity of flotation at laboratory scale. Miner. Eng. 2016, 92, 216-220. [CrossRef]

43. Neethling, S.J.; Lee, H.T.; Cilliers, J.J. Simple relationships for predicting the recovery of liquid from flowing foams and froths. Miner. Eng. 2003, 16, 1123-1130. [CrossRef]

44. Laskowski, J.S.; Tlhone, T.; Williams, P.; Ding, K. Fundamental properties of the polyoxypropylene alkyl ether flotation frothers. Int. J. Miner. Process. 2003, 72, 289-299. [CrossRef]

45. Wang, L.; Peng, Y.; Runge, K. Entrainment in froth flotation: The degree of entrainment and its contributing factors. Powder Technol. 2016, 288, 202-211. [CrossRef]

46. Diaz-Penafiel, P.; Dobby, G.S. Kinetic studies in flotation columns: Bubble size effect. Miner. Eng. 1994, 7, 465-478. [CrossRef]

47. Yoon, R.H.; Yordan, J.L. The critical rupture thickness of thin water films on hydrophobic surfaces. J. Colloid Interface Sci. 1991, 146, 565-572. [CrossRef]

48. Lekki, J.; Laskowski, J. On the dynamic effect of frother-collector joint action in flotation. Trans. Inst. Min. Metall. 1971, 80, C174.

49. Zhou, Z.A.; Plitt, L.R.; Egiebor, N.O. The effects of solids and reagents on the characteristics of coal flotation in columns. Miner. Eng. 1993, 6, 291-306. [CrossRef] 